\title{
2-Aminoethyl Diphenylborinate (2-APB) Analogues: Part 3 - Regulators of Huntington Aggregation and Transglutaminase
}

\section{Shoichiro Ozaki ${ }^{*}$}

The Institute of Physical and Chemical Research, 2-1 Hirosawa, Wako, Saitama 351-0198, Japan

\begin{abstract}
Huntington aggregation inhibitory activities and transglutaminase inhibitory activities of 2APB analogues were measured. 2-APB analogues regulated the Huntington aggregation. This fact provided an example that 2-APB analogues can regulate cellular process. Diphenyl (aminoacidonate $\mathrm{N}, \mathrm{O}$ ) boranes, which are effective regulator of $\mathrm{Ca} 2+$ release and cellular process, were effective regulators of Huntington aggregation. It was also found that many of 2-APB analogues have moderate transglutaminase inhibition activities 2-Aminoethyl di(4-trifluorophenyl) borinate is a good transglutaminase regurator.
\end{abstract}

Keywords: 2-APB; 2-APB analogue; Regulator of transglutaminase; Regulator of huntington aggregation; Huntington disease

\section{Introduction}

Extracellular signal molecules attach to the plasmatic membrane where they are recognized by cell surface receptors. Upon binding of the ligand to the appropriate receptor, activation of $\mathrm{G}$ protein activates in turn phospholipase C. Active phospholipase $C$ hydrolyzes phosphatidylinositol 4,5-bisphosphate $\left(\mathrm{PIP}_{2}\right)$ giving rise to two products: 1,2-diacylglycerol and inositol 1,4,5-triphosphate (IP ${ }_{3}$ ). $\mathrm{IP}_{3}$ stimulates the release of $\mathrm{Ca}^{2+}$ from the intracellular stores in the endoplasmic reticulum through $\mathrm{IP}_{3}$ receptor while regulating a wide range of cellular processes [1-20].

In 1997, we identified 2-aminoethyl diphenylborinate (2-APB) as being an $\mathrm{IP}_{3}$ receptor inhibitor and regulate $\mathrm{IP}_{3}$-induced calcium release $[21,22]$. This discovery rose a substantial interest and had a great impact as it gained more than 600 citations and more than 1000 studies on 2-APB [23-37] have been published so far. This was supported by increasing sales of 2-APB by Sigma-Aldrich as membrane-permeable modulator of intracellular $\mathrm{IP}_{3}$-induced cellular calcium release. We aimed to generate better modulator of calcium release than 2-APB. And we synthesized several 2-APB analogues and measured their inhibitory activities on Store-Operated Calcium Entry (SOCE) and IP Induced Calcium Release (IICR). We found that bis boron compound DBP 161 and DBP 163 were 10 times more effective than 2-APB [38]. Previously, we studied bis- boron compounds in more detail $[39,40]$. We extended these studies and synthesized 4932 -APB analogues using methods described by us [38-43] and others [44-49] and measured their inhibitory activities on SOCE and IICR [38-43]. We found that these 2-APB analogues regulate $\mathrm{Ca}^{2+}$ release and associated cellular processes. We reported these finding on mono-boron compounds [50] and on bis-boron compounds [51].

This time, we report about 2 tests how these $2 \mathrm{APB}$ analogues show the ability to regulator $\mathrm{Ca}^{2+}$ related enzyme inhibitory activity and regulation of cellular process. One test is a regulation of transglutaminase, Second test is a regulation of Huntington aggregation using $2 \mathrm{APB}$ analogs having various $\mathrm{Ca}^{2+}$ release-related activities: SOCE. We wish to tell the relations of trangltaminase activity (TG), Huntington aggregation inhibition (x-Fold) and SOCE and chemical structures of compounds.
Transglutaminases (TG) [52-54] are calcium-dependent enzymes that catalyze various post-translational modifications including protein cross-linking, amine incorporation, and deamidation. The proteincrosslink is formed with isopeptide bonds between the carboxamide group of glutamine residues and the $\beta$-amino group of lysine residues to form $\mathrm{N}$-( $\gamma$-glutamyl)-L-lysine accompanied by loss of the ammonia [55]. TG is implicated in various pathological roles in many neurodegenerative diseases [56-58] including Alzheimer's disease [59], Huntington's disease [60-63]. TG is also implicated in diseaes like catalacttous lens [64], Psoriasis skin injury [65], liver injury [66], fibrin injury [67,68], immune system injury [69,70] and Celiac disease [71]. Numeroous transglutaminase inhibitors are reported [72-75]. We have reported aryl- $\beta$-amino ketones [76], dithio $\beta$-amino ketones [77] as transglutaminase inhibitors.

We measured transglutaminase (TG) inhibitory activities and Huntington aggregation inhibitory activities (x-Fold) of 276 2APB analogues. And we analyzed the result and relation of TG, $\mathrm{x}$-Fold and SOCE IC S0.

\section{Materials and Methods}

\section{APB analogues}

2-APB was first synthesized by Ronderstvent et al. [44] in 1954 from triphenylboranes and ethanolamine. Later, hydroxy diphenyl borane and ethanolamine methods for 2-APB synthesis were reported by Weidman and Zimmermann [45], Letsinger and Skoog [46], Povlock and Lippincott [47].

We have synthesized 493 2-APB analogues [38-43] using methods described by us [38-43] and others [44-49]. The structures, names and synthetic methods of the compounds are in example 1-493 [43].

*Corresponding author: Shoichiro Ozaki, The Institute of Physical and Chemical Research, 2-1 Hirosawa, Wako, Saitama 351-0198, Japan, Tel: 81-0467670991. E-mail: ozaki-0991@m.jcnnet.jp

Received June 5, 2014; Accepted September 9, 2014; Published September 16,2014

Citation: Ozaki S (2014) 2-Aminoethyl Diphenylborinate (2-APB) Analogues: Part 3 - Regulators of Huntington Aggregation and Transglutaminase. J Bioengineer \& Biomedical Sci 4: 131. doi:10.4172/2155-9538.1000131

Copyright: (c) 2014 Ozaki S. This is an open-access article distributed under the terms of the Creative Commons Attribution License, which permits unrestricted use, distribution, and reproduction in any medium, provided the original author and source are credited. 
Citation: Ozaki S (2014) 2-Aminoethyl Diphenylborinate (2-APB) Analogues: Part 3 - Regulators of Huntington Aggregation and Transglutaminase. J Bioengineer \& Biomedical Sci 4: 131. doi:10.4172/2155-9538.1000131

Page 2 of 7

\section{Methods}

We measured transglutaminase (TG) inhibitory activities as described at ref 76 .and Huntington aggregation inhibitory activities (x-Fold) [62].

\section{Transglutaminase inhibitory activities measurement}

TG (TransGlutaminase) inhibiting activity assay: Inhibition of TG enzyme was determined by assaying the enzyme activity in accordance with an optionally modified version of the enzyme activity in accordance with an optionally modified version of the method of Lorand et al. [53]. An enzyme reaction solution $(0.1 \mathrm{ml})(100 \mathrm{mM}$ HEPES-NaOH, pH 7.5, $1 \mathrm{mM} \mathrm{CaCl}, 20 \mathrm{M}$, monodansyl cadaverine, $0.05 \mathrm{mg} / \mathrm{ml} \mathrm{N}, \mathrm{N}$-dimethylcasein, $5 \mu \mathrm{g} / \mathrm{ml}$ TGase) was introduced into wells of a 86-well plate (Nunc, 96 well Black Plate with Clear Bottom). A test compound was added in concentration of $100 \mu \mathrm{M}$. The plate was set in the fluorescence drug screening system FDSS3000 (hamamatsu Photonics K.K) TGase-inhibiting activity of the compound was calculated by assaying changes in fluorescence wavelength (at 340 $\mathrm{nm})$ per unit time. The assay level at which a fluorescence change was observed with the addition of DMSO $(1 \mu \mathrm{l})$ used as control instead of the test compound was designated as 100 . The assay level at which TGase activity decreased by half in the presence of the test compound was designated as TG 50 .

\section{Huntington aggregation inhibitory activities measurement}

Truncated N-terminal Huntington 150 Q-EGFP-Neuron 2a cells are cultured in 96 well plates. for 1day, $1 \mu \mathrm{M}$ Ponasterone A $(2 \mu \mathrm{l})$, $5 \mathrm{M}$ Dibutyl cyclic AMP $(2 \mu \mathrm{l})$ are added as to the test compound is to be $20 \mu \mathrm{M}$ and cultured for 20 hours. The cells are fixed with $4 \%$ paraformaldehyde and washed with PBS after 30 minutes, and stained with Hoechst 33342. Aggregated cell numbers and total cell numbers are counted by Array Scan V T1 (Cellomics company, Pittuburg, USA). Ratio of aggregated cell to total cells ( $\mathrm{x}$-Fold) was measured. Without test compounds, ratio of aggregated cell to total cell $\mathrm{x}$-Fold is 1 . The smaller the $\mathrm{x}$-Fold, the aggregation inhibition is stronger.

\section{SOCE inhibition activities measurement}

Inhibitory activities of the 2APB analogues for SOCE were measured using our improved assays as described previously [50].

\section{Results and Discussion}

We measured transglutaminase inhibitory activities (TG) and Huntington aggregation inhibition activity ( $\mathrm{x}$-Fold), and SOCE inhibition activities $\mathrm{IC}_{50}$ of $2 \mathrm{APB}$ analogues The results are shown in Supplementary Figure S1.

Typical 42 compounds are picked up from Figure S1 and grouped them into three groups and lined up from SOCE smaller value 0.2 to $>10$. 1) Amino acid adducts compounds, 2) Aminoalcohol adducts compounds \& 3) Aminothiol adducts compounds.

\section{Amino acid adduct compounds}

Amino acid adduct compounds are majority of effective compounds. The compounds having small $\mathrm{IC}_{50}$ (SOCE) like 0.2 showed strong Huntington aggregation inhibiting activities (x-Fold). TG has no relation with $\mathrm{IC}_{50}$ (SOCE).

TG of 911 Diphenyl (2,6-diaminohexanate-O,N) borane is 136, $\mathrm{x}$-Fold is $0.41, \mathrm{IC}_{50}$ is 0.2 . TG of 919 Diphenyl (2,3-diaminopropionate$\mathrm{O}, \mathrm{N})$ borane is 90 and $\mathrm{x}$-Fold is $0.53, \mathrm{IC}_{50}$ is 0.2 . TG of 855 Diphenyl asparaginate- $\mathrm{O}, \mathrm{N}$ - borane is $105 \mathrm{x}$-Fold is 0.54 and $\mathrm{IC}_{50}$ is 0.2 (Figure $1)$.

The compounds having big $\mathrm{IC}_{50}$ (SOCE) like 10 showed no transglutaminase activity and no Huntington aggregation activity. TG of 901 Diphenyl (methionate-O,N) borane is $106, \mathrm{x}$-Hold is $0.90, \mathrm{IC}_{50}$ is $>10$. TG of 4129 Diphenyl (2-aminohexanecarboxylate-O,N) borane is 90 , $\mathrm{x}$-Fold is $0.97, \mathrm{IC}_{50}$ is $>10$.

\section{Aminoalcohol adduct compounds}

This group compounds showed moderate transglutaminase inhibition and Huntington aggregation inhibition. 2APB belongs to this group. TG of $2 \mathrm{APB}$ is 80 , $\mathrm{x}$-Fold is $0.64, \mathrm{IC}_{50}$ is 3 . TG of 1022 Bis(4,4 (phenyl aminoethoxy boryl)phenyl)ether is 4 and $\mathrm{x}$-Fold is 0.50 ,SOCE is 0.2 . TG of 4242 -aminoethyl di(4-trifluorophenyl) borinate is 54 , $x$-Fold is 0.69 , SOCE is 0.5 . TG of 372 -aminoethyl di(5-chloro2-methyl-phenyl) borinate is $74, \mathrm{x}$-Fold is 0.78 and $\mathrm{IC}_{50}$ is 1 (Figure 2).

\section{Aminothil adduct compounds}

Some compounds of this group showed remarkable transglutaminase inhibition, showed no Huntington aggregation activities. TG of 6014 2-aminoethylthio di (4-chloro-2-fluorophenyl) borane is 28 , $\mathrm{x}$-Fold is 0.96 , SOCE is $<1$. TG of 10312 -aminoethylthio diphenyl borane is $33, \mathrm{x}$-Fold is 0.87 , and SOCE is 2. TG of 3115 2 -aminoethylthio di (3-chloro-4-methylphenyl) borane is 12 , $\mathrm{x}$-Fold is 1.01, SOCE is 2. TG of 6039 2-aminoethylthio di (4-cyanophenyl) borane is 23 . X-fold is 0.92 , SOCE is $>10$. This thiol adducts compounds showed toxicity. Cell numbers decreased during assay. Therefore this group compounds would be not suitable for clinical use.

\section{Relations of chemical structures and activities}

Active compounds of $2 \mathrm{APB}$ analogues, nitrogen atom must come in this order B-O-C-C-N as 2-APB $\mathrm{C}_{6} \mathrm{H}_{5} \mathrm{~B}\left(\mathrm{OCH}_{2} \mathrm{CH}_{2} \mathrm{NH}_{2}\right) \mathrm{C}_{6} \mathrm{H}_{5}$. The compounds having other order like $\mathrm{B}-\mathrm{O}-\mathrm{C}-\mathrm{N}$, or $\mathrm{B}-\mathrm{O}-\mathrm{C}-\mathrm{C}-\mathrm{C}-\mathrm{N}$ have no activities. When phenyl group is substituted with aliphatic or aryaliphatic group, they lost their activities. When compared mono-boron, bis-boron and poly-boron compounds, mono-boron compounds were best and bis-boron compounds come next.

\section{Relation of SOCE $\mathrm{IC}_{50}$ value and TG and $\mathrm{x}$-Fold}

Relation of SOCE IC $_{50}$ and $x$-Fold: When look at Figure S1, the compounds having strong $\mathrm{Ca}^{2+}$ release activity, low $\mathrm{IC}_{50}$ value $\left(\mathrm{IC}_{50 \mathrm{is}}<1\right)$ except aminothiol adduct compounds, showed strong Huntington aggregation inhibiting activity The compounds having weak $\mathrm{Ca}^{2+}$ releasing activity $\left(\mathrm{IC}_{50}\right.$ is $\left.>10\right)$ showed weak or no transglutaminase inhibiting activity (TG is near 100), and showed weak or no Hunting aggregation inhibiting activity ( $\mathrm{x}$-Fold is near 1 ). These results indicated that $2 \mathrm{APB}$ analogues were effective as regulators of cellular process.

Relation of SOCE $\mathrm{IC}_{50}$ and TG. Relation of TG and $\mathrm{x}$-Fold: The compounds having strong $\mathrm{Ca}^{2+}$ release activity, low $\mathrm{IC}_{50}$ value $\left(\mathrm{IC}_{50 \mathrm{i}}<1\right)$ except aminothiol adduct compounds, showed no transglutaminase inhibition activities, $\mathrm{x}$-Fold is near 1.00 even through $\mathrm{IC}_{50}$ is 0.2 . Because our assay of transglutaminase inhibition is done in vitro and the assay is not cellular process. Calcium release cannot be expected. Therefore we cannot find any relation between TG and SOCE $\mathrm{IC}_{50}$ value also we cannot find any relation between TG and $\mathrm{x}$-Fold. If we assay transglutaminase inhibition in vivo system, other results would be expected. 
Citation: Ozaki S (2014) 2-Aminoethyl Diphenylborinate (2-APB) Analogues: Part 3 - Regulators of Huntington Aggregation and Transglutaminase. J

911<smiles>CCOC(=O)C(N)CCCCN</smiles>

TG $\quad x-F o l d ~ I C 50$

919<smiles>OB(c1ccccc1)c1ccccc1</smiles>

$\begin{array}{lll}136 & 0.41 & 0.2\end{array}$<smiles>CCC(N)C(=O)O</smiles>

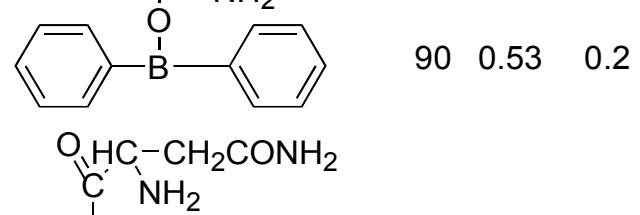

855

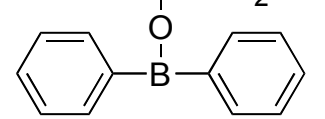

$109 \quad 0.54$

0.2<smiles>NCC(=O)C1CC1</smiles>

5019<smiles>[GeH3]</smiles><smiles>[C-]C=O</smiles><smiles>CCCc1ccc(CC)c(CC)c1</smiles>

$\mathrm{NH}_{2}$<smiles>NC(=O)CCC(N)COCO</smiles>
1024<smiles>O=Cc1ccc(B(O)c2ccccc2)cc1</smiles>

$\begin{array}{lll}24 & 0.6 & 0.2\end{array}$<smiles>NCCCNC(CN)C(=O)OB(c1ccccc1)c1ccccc1N</smiles><smiles>NC(=O)CC(N)=O</smiles>

855<smiles>OB(c1ccccc1)c1ccccc1</smiles>
$\begin{array}{lll}109 & 0.54 \quad 0.5\end{array}$ $\mathrm{CH}_{2} \mathrm{CH}_{2} \mathrm{COOH}$<smiles>NCO[C]N[C]C=O</smiles>

907<smiles>[B](c1ccccc1)c1ccccc1</smiles>

$\begin{array}{lll}86 & 0.91 & 0.7\end{array}$

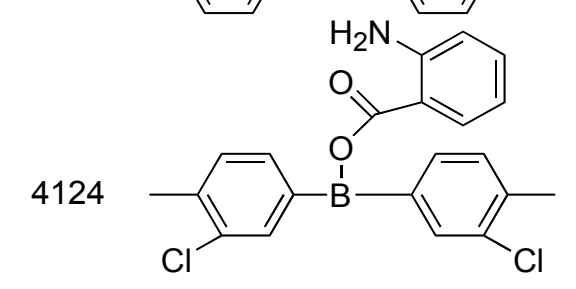

$35 \quad 0.98<1$

Figure 1: Amino acid adducts compounds.

5142<smiles>NCC(N)C(=O)O</smiles>

847<smiles>CCOB(c1ccc(C)c(Cl)c1)c1ccc(C)c(Cl)c1</smiles>

916

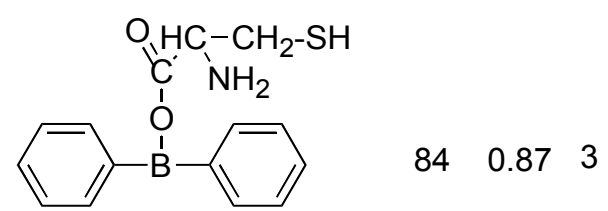

847<smiles>COB(c1ccccc1)c1ccccc1N</smiles>

$\begin{array}{lll}84 & 0.87 & 3\end{array}$

877<smiles>NOB(c1ccccc1)c1ccccc1</smiles>

$94 \quad 1.01>10$

901

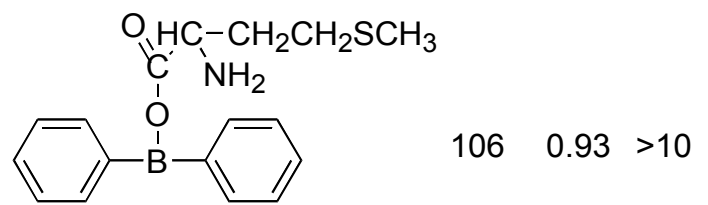

4129
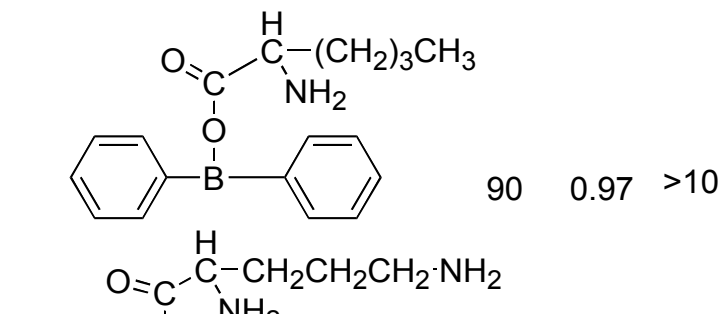

921<smiles>NOB(c1ccccc1)c1ccccc1</smiles>

$94 \quad 0.81>10$

$\mathrm{O} \mathrm{HC}-\mathrm{CH}_{2} \mathrm{CH}_{2} \mathrm{NH}_{2}$

C' $\mathrm{NH}_{2}$<smiles>OB(c1ccccc1)c1ccccc1</smiles>

$98 \quad 0.88>10$

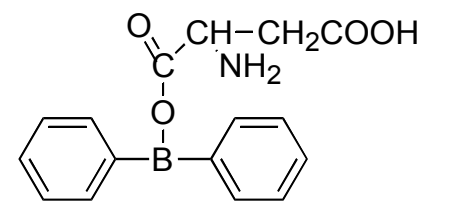

$\begin{array}{lll}92 & 0.99 & 10\end{array}$ 
Citation: Ozaki S (2014) 2-Aminoethyl Diphenylborinate (2-APB) Analogues: Part 3 - Regulators of Huntington Aggregation and Transglutaminase. J

1022<smiles>COB(c1ccccc1)c1ccc(C=O)cc1</smiles>

6033<smiles>CNCCOB(c1cc(Cl)ccc1F)c1cc(Cl)ccc1F</smiles>

$\begin{array}{llll}122 & 1.02 & 0.5 & 6032\end{array}$<smiles>[R4][14C](F)(F)c1ccc(B(OCCN)c2ccc(C(F)(F)F)cc2)cc1</smiles>

372

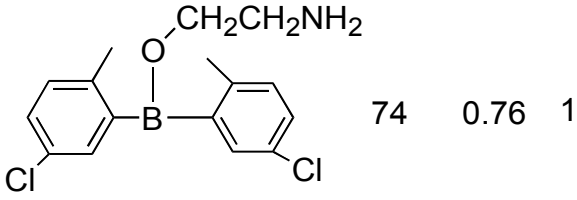

2APB

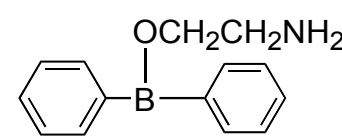

$80 \quad 0.64 \quad 3$

6023<smiles>COB(c1ccc(Cl)c(F)c1)c1ccc(Cl)c(F)c1</smiles>
1005<smiles>CCOB(c1ccccc1)c1ccccc1</smiles>

$86 \quad 0.92 \quad 3$ 4140<smiles>COB(c1ccc(Cl)c(F)c1)c1ccc(Cl)c(F)c1</smiles>

$94 \quad 1.01 \quad 5$ 4146<smiles>COB(c1ccccc1)c1ccc(Cl)c(F)c1</smiles>
$88 \quad 1.15 \quad 5$ 4145<smiles>CCOB(c1ccc(Cl)c(F)c1)c1ccc(Cl)c(F)c1</smiles>

$87 \quad 110 \quad 5$ $\mathrm{H}_{2} \mathrm{NH}_{2} \mathrm{C}$<smiles>CC(C)OB(c1cccc(Cl)c1)c1ccc(Cl)c(F)c1</smiles>

$80 \quad 1.03$

3115
6030<smiles>NCCOB(c1cc(F)cc(Cl)c1)c1cc(F)cc(Cl)c1</smiles>

6033<smiles>COB(c1cc(Cl)ccc1F)c1cc(Cl)ccc1F</smiles>
$\begin{array}{lll}111 & 0.97 \quad 15\end{array}$<smiles>CN(C)CCOB(c1ccc(Cl)c(F)c1)c1ccc(Cl)c([R4]([O])([O])O[Na])c1</smiles><smiles>NCCSB(c1ccc(Cl)cc1F)c1ccc(Cl)cc1F</smiles>
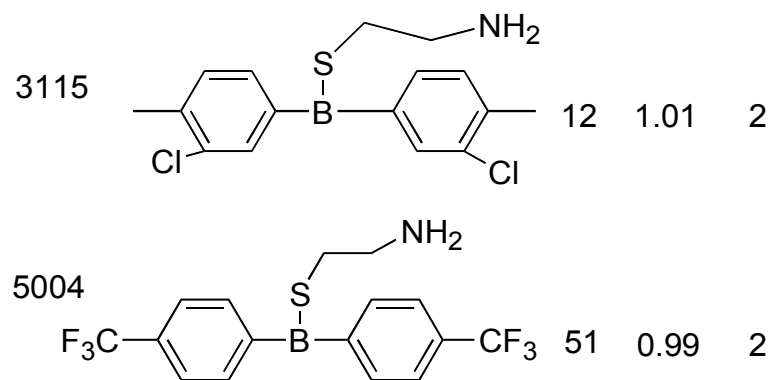
$\mathrm{NH}_{2}$

1031

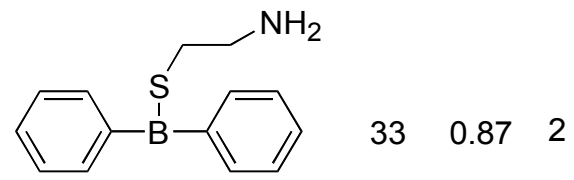
4107
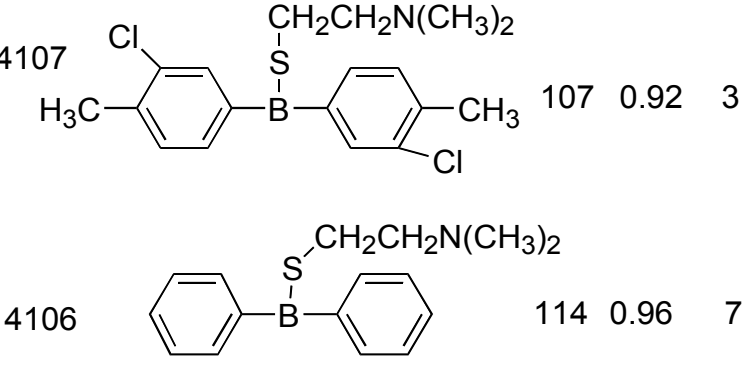

6039<smiles>N#Cc1ccc(B(SCCN)c2ccc(C#N)cc2)cc1</smiles>

Figure 2: Amino alcohol adduct compounds \& Aminothiol adduct compounds. 
Citation: Ozaki S (2014) 2-Aminoethyl Diphenylborinate (2-APB) Analogues: Part 3 - Regulators of Huntington Aggregation and Transglutaminase. J Bioengineer \& Biomedical Sci 4: 131. doi:10.4172/2155-9538.1000131

\section{Regurator of huntington aggregation}

Many compounds belong to amino acid adducts especially basic amino acid adduct such as 911 Diphenyl (2,6-diaminohexanoate 0,N)borane TG:136, x-Fold:0.41, $\mathrm{IC}_{50}: 0.2$ and 919 Diphenyl (2,3-diaminopropionate O.N) borane TG:90, x-Fold:0.53, IC $_{50}: 0.2$ showed strong Huntington aggregation inhiting activity and no transglutaminase inhibiting activity.. These compound look like to be good and selective regulator of Huntington aggregation inhibitor.

\section{Regulator of transglutaminase}

Aminoalcohol adduct, 1022 Bis-(4,4'(phenyl aminoethoxy boryl) phenyl)ether: TG: 4 and x-Fold: 0.50 SOCE:0.2 and 424 2-aminoethyl di(4-trifluorophenyl) borinate: TG: 54 , x-Fold :0.69, SOCE : 0.5 are good candidate as transglutaminase inhibitors. I have measured transglutaminase inhivition activities at $100 \mu \mathrm{M}$. The activities like these TG:4 or 54 at $100 \mu \mathrm{M}$ are not so strong as aryl $\beta$-aminoethyl ketones $\mathrm{IC}_{50}: 0.1 \mu \mathrm{M}$ reported by us [76,77] or thienopyrimidines $\mathrm{IC}_{50}$ : $0.13 \mu \mathrm{M}$ reported by Duval [74]. Transglutaminase is necessary enzyme for our lives. Strong inhibitor will give toxicity. Moderate activity is required for clinical use.. We are reporting many TG inhibitors .differing activities. People will be able to choose most suitably active compounds. Some of these compounds were shown to inhibit the calcium dependent enzyme transglutaminase [43]. Transglutaminase inhibitors block the abnormal cross-link of protein [43,76-78] and they may slow down or even stop the progression of disease caused by over cross-linked proteins, such as Huntington`s disease.

I have analyzed the SOCE and TG(trnansglutaminase inhibition activities and $\mathrm{x}$-Fold (Huntington aggregation inhibition) of $2622 \mathrm{APB}$ analogues . 2-APB analogues regulated the Huntington aggregation This fact provided an example that 2-APB analogues can regulate cellular process. DAB (Diphenyl aminoacidonate $(\mathrm{N}, \mathrm{O})$ boranes are best compounds to regulate Huntington aggregation . The $2 \mathrm{APB}$ analogues presented in this study could be excellent lead compound for therapeutically intervene in many diseases such as heart disease [26-28,32-36,79], Huntington disease [43,61,62], Celiac disease [71], Alzheimer disease [79] in connection with cross-link of protein.

\section{Conclusion}

2-APB analogues regulated the Huntington aggregation has provided an example that $2-\mathrm{APB}$ analogues can regulate cellular process. Diphenyl (aminoacidonate N,O) boranes are effective regulators of Huntington aggregation. It was also found that many of 2-APB analogues had moderate transglutaminase inhibition activities.

\section{References}

1. Berridge MJ, Dawson RM, Downes CP, Heslop JP, Irvine RF (1983) Changes in the levels of inositol phosphates after agonist-dependent hydrolysis of membrane phosphoinositides. Biochem J 212: 473-482.

2. Berridge MJ (1983) Rapid accumulation of inositol trisphosphate reveals that agonists hydrolyse polyphosphoinositides instead of phosphatidylinositol. Biochem J 212: 849-858.

3. Streb H, Irvine RF, Berridge MJ, Schulz I (1983) Release of Ca2+ from a nonmitochondrial intracellular store in pancreatic acinar cells by inositol-1,4,5trisphosphate. Nature 306: 67-69.

4. Berridge MJ, Heslop JP, Irvine RF, Brown KD (1984) Inositol trisphosphate formation and calcium mobilization in Swiss 3 T3 cells in response to plateletderived growth factor. Biochem J 222: 195-201.

5. Fein A, Payne R, Corson DW, Berridge MJ, Irvine RF (1984) Photoreceptor excitation and adaptation by inositol 1,4,5-trisphosphate. Nature 311: 157-160.
6. Brown JE, Rubin LJ, Ghalayini AJ (1984) A biochemical and electrophysiological examination of myo-inositol polyphosphate as a putative messenger for excitation in Limulus ventral photoreceptor cells. Nature 311: 160-163.

7. Burgess GM, Godfrey PP, McKinney JS, Berridge MJ, Irvine RF, et al. (1984) The second messenger linking receptor activation to internal $\mathrm{Ca}$ release in liver. Nature 309: 63-66.

8. Prentki M, Biden TJ, Janjic D, Irvine RF, Berridge MJ, et al. (1984) Rapid mobilization of $\mathrm{Ca} 2+$ from rat insulinoma microsomes by inositol-1,4,5trisphosphate. Nature 309: 562-564

9. Irvine RF, Brown KD, Berridge MJ (1984) Specificity of inositol trisphosphateinduced calcium release from permeabilized Swiss-mouse 3T3 cells. Biochem J 222: 269-272.

10. Irvine RF, Letcher AJ, Heslop JP, Berridge MJ (1986) The inositol tris/ tetrakisphosphate pathway - demonstration of Ins 1,4,5P3 3-kinase activity in animal cells. Nature 320: 631-634.

11. Rapp PE, Berridge MJ (1981) The control of transepithelial potential oscillations in the salivary gland of Calliphora erythrocephala. Exp Biol 93: 119-132.

12. Missiaen L, Taylor CW, Berridge MJ (1991) Spontaneous calcium release from inositol trisphosphate-sensitive calcium stores. Nature 352: 241-244.

13. Berridge MJ, Irvine RF (1984) Inositol trisphosphate, a novel second messenger in cellular signal transduction. Nature 312: 315-321.

14. Berridge MJ (1987) Inositol trisphosphate and diacylglycerol: two interacting second messengers. Annu Rev Biochem 56: 159-193.

15. Berridge MJ, Irvine RF (1989) Inositol phosphates and cell signalling. Nature 341: 197-205.

16. Berridge MJ, Downes CP, Hanley MR (1989) Neural and developmental actions of lithium: a unifying hypothesis. Cell 59: 411-419.

17. Berridge MJ (1993) Inositol trisphosphate and calcium signalling. Nature 361 315-325.

18. Bootman MD, Berridge MJ (1995) The elemental principles of calcium signaling Cell 83: 675-678.

19. Berridge MJ (1993) Cell signalling. A tale of two messengers. Nature 365: 388 389.

20. Decrock E, De Bock M, Wang N, Gadicherla AK, Bol M, et al. (2013) IP3, a small molecule with a powerful message. Biochim Biophys Acta 1833: 1772 1786.

21. Maruyama T, Kanaji T, Nakade S, Kanno T, Mikoshiba K (1997) 2APB 2-aminoethoxydiphenyl borate, a membrane-penetrable modulator of Ins $(1,4,5)$ P3-induced Ca2+ release. J Biochem 122: 498-505.

22. Iwasaki H, Mori Y, Hara Y, Uchida K, Zhou H, etal. (2001)2-Aminoethoxydipheny borate (2-APB) inhibits capacitative calcium entry independently of the function of inositol 1,4,5-trisphosphate receptors. Receptors Channels 7: 429-439.

23. Bilmen JG, Michelangeli F (2002) Inhibition of the type 1 inositol 1,4,5-trisphosphate receptor by 2 -aminoethoxydiphenylborate. Cell Signal 14 955-960.

24. Ma HT, Venkatachalam K, Parys JB, Gill DL (2002) Modification of storeoperated channel coupling and inositol trisphosphate receptor function by 2-aminoethoxydiphenyl borate in DT40 lymphocytes. J Biol Chem 277: 69156922.

25. Dobrydneva Y, Blackmore P (2001) 2-Aminoethoxydiphenyl borate directly inhibits store-operated calcium entry channels in human platelets. Mo Pharmacol 60: 541-552.

26. Bilmen JG, Wootton LL, Godfrey RE, Smart OS, Michelangeli F (2002) Inhibition of SERCA Ca2+ pumps by 2-aminoethoxydiphenyl borate (2-APB) 2-APB reduces both $\mathrm{Ca} 2+$ binding and phosphoryl transfer from ATP, by interfering with the pathway leading to the $\mathrm{Ca} 2+$-binding sites. Eur $\mathrm{J}$ Biochem 269: 3678-3687

27. Missiaen L, Callewaert G, De Smedt H, Parys JB (2001) 2-Aminoethoxydipheny borate affects the inositol 1,4,5-trisphosphate receptor, the intracellular $\mathrm{Ca2}+$ pump and the non-specific $\mathrm{Ca} 2+$ leak from the non-mitochondrial $\mathrm{Ca} 2+$ stores in permeabilized A7r5 cells. Cell Calcium 29: 111-116. 
Citation: Ozaki S (2014) 2-Aminoethyl Diphenylborinate (2-APB) Analogues: Part 3 - Regulators of Huntington Aggregation and Transglutaminase. J

28. Peppiatt CM, Collins TJ, Mackenzie L, Conway SJ, Holmes AB, et al. (2003) 2-Aminoethoxydiphenyl borate (2-APB) antagonises inosito 1,4,5-trisphosphate-induced calcium release, inhibits calcium pumps and has a use-dependent and slowly reversible action on store-operated calcium entry channels. Cell Calcium 34: 97-108.

29. Luo D, Broad LM, Bird GS, Putney JW Jr (2001) Signaling pathways underlying muscarinic receptor-induced $[\mathrm{Ca} 2+]$ oscillations in HEK293 cells. J Biol Chem 276: 5613-5621.

30. Bootman MD, Young KW, Young JM, Moreton RB, Berridge MJ (1996) Extracellular calcium concentration controls the frequency of intracellular calcium spiking independently of inositol 1,4,5-trisphosphate production in HeLa cells. Biochem J 314: 347-354.

31. Mackenzie L, Bootman MD, Berridge MJ, Lipp P (2001) Predetermined recruitment of calcium release sites underlies excitation-contraction coupling in rat atrial myocytes. J Physiol 530: 417-429.

32. Lipp P, Laine M, Tovey SC, Burrell KM, Berridge MJ, et al. (2000) Functiona InsP3 receptors that may modulate excitation-contraction coupling in the heart. Curr Biol 10: 939-942.

33. Mackenzie L, Bootman MD, Laine M, Berridge MJ, Thuring J, et al. (2002) The role of inositol 1,4,5-trisphosphate receptors in $\mathrm{Ca}(2+)$ signalling and the generation of arrhythmias in rat atrial myocytes. J Physiol 541: 395-409.

34. Proven A, Roderick HL, Conway SJ, Berridge MJ, Horton JK, et al. (2006) Inositol 1,4,5-trisphosphate supports the arrhythmogenic action of endothelin-1 on ventricular cardiac myocytes. J Cell Sci 119: 3363-3375.

35. Berridge MJ, Bootman MD, Roderick HL (2003) Calcium signalling: dynamics, homeostasis and remodelling. Nat Rev Mol Cell Biol 4: 517-529.

36. Berridge MJ (2006) Remodelling Ca2+ signalling systems and cardiac hypertrophy. Biochem Soc Trans 34: 228-231.

37. Berridge MJ (2006) Calcium microdomains: organization and function. Cell Calcium 40: 405-412.

38. Zhou H, Iwasaki H, Nakamura T, Nakamura K, Maruyama T, et al. (2007) 2-Aminoethyl diphenylborinate analogues: selective inhibition for storeoperated Ca2+ entry. Biochem Biophys Res Commun 352: 277-282.

39. Suzuki AZ, Ozaki S, Goto J, Mikoshiba K (2010) Synthesis of bisboron compounds and their strong inhibitory activity on store-operated calcium entry. Bioorg Med Chem Lett 20: 1395-1398.

40. Goto J, Suzuki AZ, Ozaki S, Matsumoto N, Nakamura T, et al. (2010) Two novel 2-aminoethyl diphenylborinate (2-APB) analogues differentially activate and inhibit store-operated $\mathrm{Ca}(2+)$ entry via STIM proteins. Cell Calcium 47 $1-10$.

41. Mikoshiba K, Ozaki S, Suzuki A, Nakamura T (2007) Preparation of bisboron compounds controlling calcium concentration in cells.

42. Mikoshiba K, Nukina N, Ozaki S, Hamada K, Gota JL, et al. (2010) Protein crosslinking inhibitor.

43. Rondestvedt CS, Scriber RM, Wulfman CE (1995) Alcoholysis of triarylboranes J Org Chem 20: 9-12.

44. Weidmann H, Zimmerman HK (1959) Borsäure-ester von N-substituierten Aminoalkoholen. Justus Liebigs Ann Der Chemie 619: 28-35.

45. Letsinger RL, Skoog IJ (1955) Organoboron Compounds. IV. Aminoethyl Diarylborinates. J Am Chem Soc 77: 2491-2494.

46. Povlock TP, Lippincott WT (1958) The Reaction of Trimethoxyboroxine with Aromatic Grignard Reagents. J Am Chem Soc 80: 5409-5411.

47. Brown HC, Colet TE (1983) A simple preparation of boronic esters from organolithium reagents and selected trialkoxyboranes. Organometallics 2: 1316-1319.

48. Mori Y, Kobayashi J, Manabe K, Kobayashi S (2002) Use of boron enolates in water. The first boron enolate-mediated diastereoselective aldol reactions using catalytic boron sources. Tetrahedron 58: 8263-8268.

49. Ozaki S, Suzuki AZ, Bauer PO, Ebisui E, Mikoshiba K (2013) 2-Aminoethyl diphenylborinate (2-APB) analogues: regulation of $\mathrm{Ca} 2+$ signaling. Biochem Biophys Res Commun 441: 286-290.

50. Ozaki S (2014) 2-Aminoethyl diphenylborinate (2-APB) analogues: Part 2.Regulators of $\mathrm{Ca} 2+$ release and consequent cellular processes. Arches of Physiology 1: 1-6.
51. Griffin M, Casadio R, Bergamini CM (2002) Transglutaminases: nature's biological glues. Biochem J 368: 377-396

52. Lorand L, Graham RM (2003) Transglutaminases: crosslinking enzymes with pleiotropic functions. Nat Rev Mol Cell Biol 4: 140-156.

53. Selkoe DJ, Abraham C, Ihara Y (1982) Brain transglutaminase: in vitro crosslinking of human neurofilament proteins into insoluble polymers. Proc Nat Acad Sci U S A 79: 6070-6074.

54. Lorand L (1996) Neurodegenerative diseases and transglutaminase. Proc Nat Acad Sci U S A 93: 14310-14313.

55. Hoffner G, Djian P (2005) Transglutaminase and diseases of the central nervous system. Front Biosci 10: 3078-3092.

56. Malorni W, Farrace MG, Rodolfo C, Piacentini M (2008) Type 2 transglutaminase in neurodegenerative diseases: the mitochondrial connection. Curr Pharm Des 14: $278-288$.

57. Norlund MA, Lee JM, Zainelli GM, Muma NA (1999) Elevated transglutaminaseinduced bonds in PHF tau in Alzheimer's disease. Brain Res 851: 154-163.

58. Jeitner TM, Matson WR, Folk JE, Blass JP, Cooper AJ (2008) Increased levels of gamma-glutamylamines in Huntington disease CSF. J Neurochem 106: 37 44

59. Karpuj MV, Becher MW, Springer JE, Chabas D, Youssef S, et al. (2002) Prolonged survival and decreased abnormal movements in transgenic mode of Huntington disease, with administration of the transglutaminase inhibitor cystamine. Nat Med 8: 143-149.

60. Mastroberardino PG, lannicola C, Nardacci R, Bernassola F, De Laurenzi V, et al. (2002) 'Tissue' transglutaminase ablation reduces neuronal death and prolongs survival in a mouse model of Huntington's disease. Cell Death Differ 9: 873-880.

61. Bauer PO, Hudec R, Ozaki S, Okuno M, Ebisui E, et al. (2011) Genetic ablation and chemical inhibition of IP3R1 reduce mutant huntingtin aggregation. Biochem Biophys Res Commun 416: 13-17.

62. Bauer PO, Hudec R, Goswami A, Kurosawa M, Matsumoto G, et al. (2012) ROCK-phosphorylated vimentin modifies mutant huntingtin aggregation via sequestration of IRBIT. Mol Neurodegener 7: 43

63. Azari P, Rahim I, Clarkson DP (1981) Transglutaminase activity in normal and hereditary cataractous rat lens and its partial purification. Curr Eye Res 1: 463469.

64. Schroeder WT, Thacher SM, Stewart-Galetka S, Annarella M, Chema D, et al. (1992) Type I keratinocyte transglutaminase: expression in human skin and psoriasis. J Invest Dermatol 99: 27-34.

65. Tatsukawa H, Fukaya Y, Frampton G, Martinez-Fuentes A, Suzuki K, et al (2009) Role of transglutaminase 2 in liver injury via cross-linking and silencing of transcription factor Sp1. Gastroenterology 136: 1783-1795.

66. Lorand L, Rule NG, Ong HH, Furlanetto R, Jacobsen A, et al. (1968) Amine specificity in transpeptidation. Inhibition of fibrin cross-linking. Biochemistry 7 : 1214-1223.

67. Stenberg P, Nilsson JL, Eriksson O, Lundén R (1971) Fibrin-stabilizing factor inhibitors. II. The inhibitory properties of various aliphatic amines. Acta Pharm Suec 8: 415-422.

68. Fésüs L (1982) Transglutaminase activation: significance with respect to immunologic phenomena. Surv Immunol Res 1: 297-304.

69. Piper JL, Gray GM, Khosla C (2002) High selectivity of human tissue transglutaminase for immunoactive gliadin peptides: implications for celiac sprue. Biochemistry 41: 386-393.

70. Hovhannisyan Z, Weiss A, Martin A, Wiesner M, Tollefsen S, et al. (2008) The role of HLA-DQ8 beta57 polymorphism in the anti-gluten T-cell response in coeliac disease. Nature 456: 534-538.

71. Watts RE, Siegel M, Khosla C (2006) Structure-activity relationship analysis of the selective inhibition of transglutaminase 2 by dihydroisoxazoles. J Med Chem 49: 7493-7501.

72. Pardin C, Pelletier JN, Lubell WD, Keillor JW (2008) Cinnamoyl inhibitors of tissue transglutaminase. J Org Chem 73: 5766-5775

73. Duval E, Case A, Stein RL, Cuny GD (2005) Structure-activity relationship study of novel tissue transglutaminase inhibitors. Bioorg Med Chem Lett 15: 1885-1889. 
Citation: Ozaki S (2014) 2-Aminoethyl Diphenylborinate (2-APB) Analogues: Part 3 - Regulators of Huntington Aggregation and Transglutaminase. J Bioengineer \& Biomedical Sci 4: 131. doi:10.4172/2155-9538.1000131

Page 7 of 7

74. Choi K, Siegel M, Piper JL, Yuan L, Cho E, et al. (2005) Chemistry and biology of dihydroisoxazole derivatives: selective inhibitors of human transglutaminase 2. Chem Biol 12: 469-475.

75. Ozaki S, Ebisui E, Hamada K, Goto J, Suzuki AZ, et al. (2010) Potent transglutaminase inhibitors, aryl beta-aminoethyl ketones. Bioorg Med Chem Lett 20: 1141-1144.

76. Ozaki S, Ebisui E, Hamada K, Suzuki AZ, Terauchi A, et al. (2011) Poten transglutaminase inhibitors, dithio $\hat{\imath}^{2}$-aminoethyl ketones. Bioorg Med Chem Lett 21: 377-379.

77. Berridge MJ (1998) Neuronal calcium signaling. Neuron 21: 13-26.

78. Berridge MJ (2010) Calcium hypothesis of Alzheimer's disease. Pflugers Arch 459: 441-449.

79. Berridge MJ (2013) Dysregulation of neural calcium signaling in Alzheimer disease, bipolar disorder and schizophrenia. Prion 7: 2-13. 